\title{
The Urgence Of Counseling Guidance In Developing Student Discipline in Junior high school Muhammadiyah Tebing Tinggi
}

\author{
Nurussakinah Daulay, Solihah Titin Sumanti, Faisal, M. Fajri Syahroni Siregar
}

UIN North Sumatera, Indonesia

syahronisiregar1404@gmail.com

Submitted : 2021-11-24, Revised : 2021-11-27, Accepted : 2021-11-30

\begin{abstract}
This study examines the urgency of counseling guidance in fostering student discipline at the Muhammadiyah Tebing Tinggi Private Junior High School. This research is based on the existence of student discipline problems at school. The disciplinary behavior is related to violations of the rules and regulations set by the school. Schools as a strategic place to overcome students' undisciplined approach require a counseling approach. This study aims to analyze the importance of counseling guidance in fostering student discipline. This study uses a qualitative method with a phenomenological approach. Data was collected by using observation techniques, in-depth interviews, and documentation studies. Research informants consisted of principals, BK teachers, and students. The results of this study indicate that the efforts made by schools in fostering student discipline are by providing counseling and punishment services. It is hoped that with these efforts, students will be able to behave in an orderly discipline, always in an orderly manner with regulations everywhere.
\end{abstract}

Keywords: Counseling; Discipline; Urgent

\section{Introduction}

Quality education is an effort to build and realize the ideals of Indonesia to progress. Moreover, quality education should be able to integrate the three main areas of activity in synergy, namely the administration and leadership fields, the instructional and curricular fields, and the student development fields (Joseph, 2006). There are many types of student problems at school. Their way of thinking becomes divided with problems outside school and inside school. An act of school service to students with counseling guidance that directs students to find out their talents and potential.

The problem of violations that often occur by students in schools has become an important problem that needs serious attention by guidance and counseling teachers. This matter is very important and must be considered because the problems experienced by students will have a negative impact, both on students and on their environment which will cause discomfort in learning. The students finally really need help from the supervisor so that what is experienced by students and students such as students and students who are not disciplined violates the rules. A counseling approach is needed to deal with students and students who violate the rules (Muawanah, 2012).

Guidance is the process of providing assistance to individuals to achieve the understanding and self-direction needed to make maximum adjustments to school, family and society (Hamalik, 2011). Guidance and Counseling is a technique in counseling guidance services with the aim that the counselee is able to gain a better understanding of himself to solve the problems he is experiencing and direct himself to be able to develop his potential towards more optimal development so as to achieve happiness (Gibson, 2011).

The counseling approach is basically done individually in the form of giving advice. Glen E. Smith quoted argues that counseling is a relationship between a person and another person and strives to help others to understand problems so that problems can be solved in the context of adjustment (Willis, 2013). However, in Islam, guidance and counseling can be used as a medium of da'wah, because the practice of counseling in Islam is not a new matter. Even Islamic counseling existed when the teachings of Islam were revealed to the Prophet Muhammad. At that time, counseling was a form of da'wah carried out by the Prophet (Rozikan, 2017). The practice of the Prophet in solving various problems faced by the 
Companions is recorded as an interaction as is now used by the counselor with the counselee, both in groups (for example in the halaqah ad-dars model) or individually (Lubis, 2007).

Saiful Akhyar Lubis explained that counseling is a process of providing assistance to individuals to realize their existence as God's creatures who should live in harmony with God's provisions and instructions, so that they can achieve happiness in this world and the hereafter (Lubis, 2007). Guidance and counseling usually talk about psychological aspects, this will be very important if there are many psychological disorders in students who are usually depressed and unable to catch lessons well (Sahir et al., 2017). Counseling guidance is also very important in its position to guide students to motivate themselves that they are unique and competitive individuals.

Guidance and counseling is one component in the overall education system, especially in schools; The teacher is one of the supporters of the implementing element of education who has the responsibility to support the implementation of educational guidance services in schools (Lase, 2018). The education process in schools does not only require school subject matter, because counseling and guidance materials are also necessary, because basically every life has problems. (Setianingsih et al., 2019). Indeed, some people can solve their own problems, but not a few people who need the help of others to solve these problems. So if students are still left to have problems without being helped, how can students concentrate on understanding or thinking about their lessons. So, if there is still a load of other thoughts. Therefore, guidance and counseling in schools is very necessary (Warif, 2019).

Discipline is an effort to get used to controlling behavior, emotions, managing time well, being able to have high discipline in individuals to be more organized, obeying the rules by dressing according to the requirements set by the school, not violating and making noise (Kristiyowati \& Afiqi, 2021). Therefore, it is necessary to have rules or regulations applied in schools to familiarize students to be able to condition behavior and bring up personal discipline appropriately. Disciplined students are students who are able to control behavior, obey all the rules imposed by the school. Discipline in children must be carried out, one of which is discipline must be reasonable and there are disciplinary sanctions if violated. According to Deni Siregar, it is very important to pay attention to discipline in school-age children, the existence of clear and directed regulations, because discipline greatly affects children in later adulthood (Rudiantoro \& Siregar, 2012).

Schools must have or have efforts in fostering disciplinary behavior towards problematic students, especially those related to violations of school discipline (Wini et al., 2020). So Guidance and Counseling teachers and homeroom teachers work together in fostering the disciplined behavior of problematic students. The coaching is through a disciplinary approach that refers to the rules and regulations that apply in the school (rules) and the sanctions.

To foster this disciplinary behavior, schools take a disciplinary approach by reminding them of school rules, providing direction to students with a Guidance and Counseling approach. The handling of problematic students refers to the rules and regulations (rules) that apply in schools and the sanctions in preventing and overcoming the occurrence of deviant behavior in students. For handling problematic students, it is suitable to apply Guidance and Counseling, because it prioritizes healing efforts by not using any form of sanctions but rather relying on interpersonal relationships, namely mutual trust between Guidance and Counseling teachers and students with problems. This allows students to understand and accept the process step by step. Of course, he can direct himself to achieve good adjustment.

Efforts to handle students who have problems with this Guidance and Counseling approach must exist in an educational institution, especially homeroom teachers and Guidance and Counseling teachers. Because the homeroom teacher knows more about the level of development of the students he teaches. And not many schools use Guidance and Counseling as an effort to handle problematic students by relying on sanctions for students who violate. 
Based on initial observations made by researchers on September 4, 2020, researchers saw several students who violated school rules. Based on these observations, the authors interpret that the level of discipline of students at the Muhammadiyah Tebing Tinggi Private Junior High School is still low. Based on the above background, the authors are interested in conducting a research entitled "The Urgency of Counseling Guidance in Fostering Student Discipline at Muhammadiyah Tebing Tinggi Private Junior High School." The purpose of this study was to determine the implementation of counseling guidance by guidance and counseling teachers at the Tebing Tinggi Muhammadiyah Private Junior High School, to determine the condition of student discipline at the Tebing Tinggi Muhammadiyah Private Junior High School, to determine the urgency of Islamic Guidance and Counseling in enforcing student discipline at Muhammadiyah Private Junior High School. High cliff.

\section{Methods}

This research is a qualitative research in the form of social studies with study specifications (objects) about or regarding the activities of supervising teachers in counseling guidance at the Muhammadiyah Tebing Tinggi Private Junior High School. The research was conducted to determine the importance of counseling guidance in fostering discipline of the students of the Muhammadiyah Tebing Tinggi Private Junior High School.

The researcher took the research location as a place to obtain data and information at the Muhammadiyah Tebing Tinggi Private Junior High School. whose address is at Jalan Sisingamaraja, Bandar Sono Village, Padang Hulu District, Tebing Tinggi City. Data collection techniques in this study used techniques that were adapted to the situation and conditions in the research field. Among them are interview, observation and documentation techniques.

\section{Results and Discussion}

Private Junior High School Muhammadiyah Tebing Tinggi has quite good student discipline, this is because there are still students who violate school rules such as dressing poorly, coming late to school, not doing homework, pulling out and smoking outside the school environment. This is in accordance with the opinion that the indicators of student discipline include (Chan et al., 2019):

a. Complete tasks on time.

b. Take care of each other with friends so that all class assignments are carried out properly.

c. Invite friends to maintain class order.

d. Remind friends who break the rules with polite and non-offensive words.

e. Dress modestly and neatly.

f. Obey school rules.

g. Discipline is a thing

Discipline is the most important thing instilled in students. Discipline is a positive habit that becomes a reference for students in managing their future. When students are able to refrain from violating the rules that have been set, this will carry over until the student is an adult and is in the community and work environment. This is in accordance with Tabrani's opinion that discipline is necessary in educating students so that students will easily be able to:

a. Discipline brings the learning process towards high productivity or produces high quality learning.

b. Discipline affects our activities in the learning process, because discipline greatly affects creativity and learning activities.

c. Discipline strengthens us to obtain satisfactory learning outcomes.

d. Discipline makes it easy for us to get satisfactory learning outcomes

e. Discipline provides readiness for educators to carry out the teaching and learning process.

f. Discipline will support positive things in carrying out various activities and learning 
processes (Rohman, 2018).

This discipline is the most important thing instilled in students from school. So, schools should actually have officers in enforcing discipline against students. BK teachers are school components whose duties are in counseling which in practice is to help individuals identify themselves, understand the nature they were born with and help individuals to become good individuals in accordance with God's commands to achieve happiness in life in this world and the hereafter.

Discipline in Islam is associated with the concept of Ihsan, namely akklah or good deeds. Ihsan is giving an understanding that one way to get closer to Allah SWT. that is to do all the commands of Allah swt. and stay away from all His prohibition (Masruroh et al., 2021). When students believe in Islam in themselves, namely by believing and carrying out the pillars of Islam in their lives and then having faith, namely by understanding and believing in the six pillars of faith plus having Ihsan in themselves, namely being able to behave in accordance with religious rules and sharia, the student will go to Insan Kamil. .

Ihsan teaches us that all human behavior is noticed by Allah SWT. Thus we will always be careful in acting and acting. Ihsan in everyday life includes obeying all the rules that apply. This includes complying with the regulations imposed in the educational environment. Students who go to Insan Kamil must be able to behave in accordance with their position as students.

Guidance and counseling carried out at the Muhammadiyah Tebing Tinggi Private Junior High School should be a forum in providing classical services to students so that disciplinary problems do not arise in students' lives. Because the background needs to be given counseling to students, namely: First, the problem of individual development. Second, the problem of individual differences. Third, the problem of individual needs, Fourth, the problem of adjustment, Fifth, the problem of the learning process.

The provision of guidance and counseling services to students will have a good impact in shaping student discipline and must also be able to assist students in developing the potential that exists in students, so that students have good life goals. Students who violate school rules may not know or understand the rules at school. Therefore, when students enter the school gate, students are introduced to the rules at school through orientation services. Rules and punishments are quite difficult and unpleasant for students, so there is also a need for rewards. Reward is something that needs to be considered in disciplining children. Rewards are not only in the form of material but can also be in the form of praise and appreciation. The existence of rewards will motivate students to be disciplined and carry out the rules with pleasure.

Consistency also needs to be considered in disciplining students. Teachers must be consistent, one way is to make an agreement or agreement with students while in the school environment regarding the rules that must be implemented. The attitude of consistency that is built in students will be able to instill a disciplined attitude in these students. The presence of guidance and counseling services can help students in dealing with or preventing problems in their lives. All aspects of the service cover all aspects of student life in the family, education and community environments. Therefore, schools need to coordinate with parents in shaping the character of students to become superior and noble individuals in accordance with shared expectations.

\section{Conclusions and Suggestions}

Based on the results of the research discussion, it can be concluded that the implementation of Guidance and Counseling at the Muhammadiyah Tebing Tinggi Private Junior High School is still not going well, because the Guidance and Counseling carried out are incidental. The implementation of guidance and counseling does not run optimally and is 
also influenced by several factors such as BK teachers who do not have BK educational qualifications, unavailability of guidance and counseling hours, school demands that make BK teachers as subjects. teachers and attitudes. students who still regard the guidance and counseling teacher as a feared teacher. Guidance and counseling services carried out by BK teachers have not been able to enforce student discipline at the Muhammadiyah Tebing Tinggi Private Junior High School. Suggestions for further researchers are to conduct research related to guidance and counseling services to improve student discipline.

\section{References}

Chan, F., Kurniawan, A. R., Melinda, L. G., Priantini, R., Zubaedah, Z., Suharti, S. R., \& Khodijah, S. (2019). Implementasi Pendidikan Karakter Disiplin Pada Peserta Didik di SD Negeri 187/1 Teratai. Pendas Mahakam: Jurnal Pendidikan Dasar, 4(2), 137-145.

Gibson, D. G. (2011). Enzymatic assembly of overlapping DNA fragments. Methods in Enzymology, 498, 349-361.

Hamalik, O. (2011). Curriculum and learning. Jakarta: Earth Script.

Joseph, J. E. (2006). Language and politics. Edinburgh University Press.

Kristiyowati, E., \& Afiqi, M. A. (2021). Korelasi Disiplin Dalam Pembelajaran PAI Dengan Religiusitas (Studi Kasus Siswa Kelas IX SMP Negeri 1 Adipala Tahun Ajaran 2019/2020). Jurnal Tawadhu, 5(1), 59-77.

Lase, S. (2018). Hubungan antara motivasi dan kebiasaan belajar terhadap prestasi belajar matematika siswa smp. Jurnal Warta Edisi, 56, 1-829.

Lubis, S. (2007). Ilmu Negara.

Masruroh, S., EQ, N. A., \& Suhartini, A. (2021). Implementasi Nilai Iman, Islam Dan Ihsan Pada Pendidikan Agama Di Perguruan Tinggi Umum. MUNTAZAM: Jurnal Manajemen Pendidikan Islam, 2(01).

Muawanah, L. B. (2012). Kematangan emosi, konsep diri dan kenakalan remaja. Persona: Jurnal Psikologi Indonesia, 1(1).

Rohman, F. (2018). Peran Pendidik Dalam Pembinaan Disiplin Siswa di Sekolah/Madrasah. Ihya Al-Arabiyah: Jurnal Pendidikan Bahasa Dan Sastra Arab, 4(1).

Rozikan, M. (2017). Transformasi dakwah melalui konseling islami. INJECT (Interdisciplinary Journal of Communication), 2(1), 77-98.

Rudiantoro, R., \& Siregar, S. V. (2012). Kualitas laporan keuangan umkm serta prospek implementasi SAK ETAP. Jurnal Akuntansi Dan Keuangan Indonesia, 9(1), 1-21.

Sahir, S. H., Rosmawati, R., \& Minan, K. (2017). Simple additive weighting method to determining employee salary increase rate. Int. J. Sci. Res. Sci. Technol, 3(8), 42-48.

Setianingsih, T. Y., Wiyatno, A., Hartono, T. S., Hindawati, E., Dewantari, A. K., Myint, K. S., Lisdawati, V., \& Safari, D. (2019). Detection of multiple viral sequences in the respiratory tract samples of suspected Middle East respiratory syndrome coronavirus patients in Jakarta, Indonesia 2015-2016. International Journal of Infectious Diseases, $86,102-107$.

Warif, M. (2019). Strategi Guru Kelas dalam Menghadapi Peserta Didik yang Malas Belajar. TARBAWI: Jurnal Pendidikan Agama Islam, 4(01), 38-55.

Willis, P. (2013). The ethnographic imagination. John Wiley \& Sons. 
Wini, M. K. M., Laksana, D. N. L., \& Awe, E. Y. (2020). Pengembangan bahan ajar multilingual berbasis konten dan konteks budaya lokal etnis ngada pada tema diriku untuk siswa kelas I sekolah dasar. Jurnal Pendidikan Dasar Flobamorata, 1(2), 73-80. 